\title{
Particulate Matter and Respiratory Diseases: How Far Have We Gone?
}

\author{
Wang $\mathrm{J}^{1}$, Chen $\mathrm{S}^{1}$, Zhu $\mathrm{M}^{1}$, Miao $\mathrm{C}^{2}$, Song $\mathrm{Y}^{1^{\star}}$ and $\mathrm{He}^{\mathrm{H}^{\star}}$
}

${ }^{1}$ Department of Pulmonary Medicine, Zhongshan Hospital, Fudan University, Shanghai 200030, P.R. China

${ }^{2}$ Department of Anesthesiology, Fudan University Shanghai Cancer Center; Department of Oncology, Shanghai Medical College, Fudan University, Shanghai 200032, P.R. China

\begin{abstract}
Air pollution is a potential threat to public health worldwide, especially in South Asia. The Global Burden of Diseases, Injuries, and Risk Factors Study 2016 (GBD 2016) reported that most of global deaths attributable to ambient particulate matter occurred in China and India. Particulate matter (PM), as the main air pollutant, is receiving increasing attention due to its specific biological properties. PM is a complicated mixture and varies in sizes, compositions and sources. Increasing epidemiological studies have shown that both short- and long-term PM exposure are associated with the morbidity and mortality of respiratory diseases, including chronic obstructive pulmonary disease (COPD), asthma, lung cancer, and pneumonia, especially in the elderly and children. Several potential biological mechanisms have been proposed to explain the adverse effect of PM on the respiratory diseases, including oxidant stress, pro-inflammation, epigenetic modifications, DNA damage and carcinogenesis. However, there are still some contradictions with regard to the role of PM in the development of these respiratory diseases. Thus, this review made a summary of results from epidemiological studies about the association between PM and COPD, asthma, lung cancer, and pneumonia, and elucidated its potential biological mechanisms.
\end{abstract}

Keywords: Particulate matter; Respiratory diseases; Adverse effect; Epidemiology

Abbreviations: PM: Particulate Matter; ED: Emergency Department; HAs: Hospital Admissions; RR: Risk Ratio; OR: Odds Ratio; CI: Confident Interval.

\section{Background}

Particulate matter (PM) is a key component of air pollution, which causes a public health challenge around the world, especially in developing countries. It has been estimated that $92 \%$ of the world's population live in places where the World Health Organization (WHO) air quality guidelines levels are not met for PM2.5 [1]. The Global Burden of Diseases, Injuries, and Risk Factors Study 2016 (GBD 2016) showed that PM had increased to the sixth with 105.7 million global disability-adjusted life-years (DALYs) in overall ranking and contributed to approximately 4.1 million deaths worldwide in 2016. Of these, most of PM-related DALYs and deaths occurred in the South Asia, especially in China and India [2]. It was estimated that PM caused about 1.1 million deaths in China in 2016 [3]. However, a national study in China showed that PM2.5 exposure contributed to 1.5 million total deaths, which was higher than that was estimated by GBD 2016 [4]. Therefore, the current health burden attributable to PM exposure is heavier than we considered.

Recently, several epidemiological and experimental studies have demonstrated that PM exposure is associated with the morbidity and mortality of cardiopulmonary diseases, such as chronic obstructive pulmonary disease (COPD), asthma, lung cancer, pneumonia, ischemic heart disease, and stroke [5,6]. It is estimated that air pollution contributes to $5 \%$ of all cardiopulmonary deaths worldwide [7]. Besides, PM contributes to diabetes and premature birth $[8,9]$. As airways and lungs are the first affected targets of air pollutants, PM deposits can cause a series of biological responses in lung cells, including oxidant stress, pro-inflammation, cytotoxicity, epigenetic changes and carcinogenesis [10]. Thus, the review focused on the results from meta-analysis and several multicentre studies to analyze the associations between PM exposure and the morbidity and mortality of respiratory diseases, including COPD, asthma, lung cancer and pneumonia. The potential biological mechanisms were elucidated to provide a brief overview of health effects of PM exposure on respiratory system.

\section{The Definition of PM}

PM is a complicated mixture with different sizes and chemical components. According to their aerodynamic diameters, $\mathrm{PM}$ is divided into coarse $(\leq 10 \mu \mathrm{m}$ and $>2.5 \mu \mathrm{m}$; PM10), fine $(\leq 2.5 \mu \mathrm{m}$ and $>0.1$ $\mu \mathrm{m}$; PM2.5) and ultrafine $(\leq 0.1 \mu \mathrm{m}$; PM0.1) particles [6]. PM10 is usually deposited in the nasal cavity and upper airways because of the respiratory barrier. However, PM2.5 and PM0.1 can escape from these barriers and directly enter the lower airways through breathing, and can even penetrate into the circulation system through lung gasblood exchange regions and cause damage to the entire body [10] Approximately $60 \%$ and $20 \%$ of total PM depositions in the lung are found to be ultrafine and fine particles, respectively [6]. Moreover, PM2.5 makes up $96 \%$ of particles retained in the lung parenchyma [11]. Thus, PM2.5 and PM0.1 have more destructive effects on the lung. Besides, the components of PM are also complicated and diverse in different areas and seasons. Generally, PM is composed of inorganic matter (including sulfates, nitrates, ammonium, acids, heavy metals, polycyclic aromatic hydrocarbons, and crustal material) and biological materials (including allergens and microbial compounds) [12].

PM is usually made up of primary and secondary PM from both anthropogenic and natural sources. Primary PM is directly emitted from different sources, including agricultural activities, industrial

*Corresponding author: Hong $\mathrm{He}$, Department of Anesthesiology, Fudan University Shanghai Cancer Center; Department of Oncology, Shanghai Medical College, Fudan University, Shanghai 200032, P.R. China; E-mail: hyc_hong@163. com

Yuanlin Song, Department of Pulmonary Medicine, Zhongshan Hospital, Fudan University, No.180 Fenglin Road, Shanghai 200030, P.R. China, Tel: +86-02164041990; E-mail: ylsong70@163.com

Received July 18, 2018; Accepted August 01, 2018; Published August 07, 2018

Citation: Wang J, Chen S, Zhu M, Miao C, Song Y, et al. (2018) Particulate Matter and Respiratory Diseases: How Far Have We Gone?. J Pulm Respir Med 8: 465. doi: 10.4172/2161-105X.1000465

Copyright: @2018 Wang J, et al. This is an open-access article distributed under the terms of the Creative Commons Attribution License, which permits unrestricted use, distribution, and reproduction in any medium, provided the original author and source are credited. 
processes, the transportation sector, construction sites and forest fires [13]. Secondary PM is derived from complex chemical reactions of gases in the atmosphere. For example, sulfur dioxide and nitrogen oxides can be converted into sulfate and nitrate particles to form the main components of fine particles [14]. The latest update of air quality guidelines (AQG) for PM from the WHO in 2005 showed that the PM10 values were limited to an annual mean of $20 \mu \mathrm{g} / \mathrm{m}^{3}$ and a 24 -hour mean of $50 \mu \mathrm{g} / \mathrm{m}^{3}$, while the values of PM2.5 were limited to an annual mean of $10 \mu \mathrm{g} / \mathrm{m}^{3}$ and a 24 -hour mean of $25 \mu \mathrm{g} / \mathrm{m}^{3}$ (not to be exceeded for more than 3 days/year) [15].

\section{The Effect of PM Exposure on Respiratory Diseases}

Epidemiological evidences show that both short- and long-term PM exposure have a close association with the development of respiratory diseases, such as COPD, asthma, lung cancer and pneumonia [16,17]. Moreover, strong evidences have demonstrated that PM exposure increases the mortality of patients with respiratory diseases [18-20]. In China, a nationwide analysis showed that the mortality from respiratory diseases increased $0.29 \%$ with a $10 \mu \mathrm{g} / \mathrm{m}^{3}$ increment in PM2.5 every 2 days [21]. Additionally, PM exposure increases respiratory symptoms and medication use, and decreases pulmonary function [7]. All populations are threatened by PM exposure, but the elderly and children are the most susceptible. Now, numerous studies, especially the meta-analysis studies, have evaluated the health risk values of PM for different respiratory diseases (Table 1).

\section{PM and COPD}

COPD is a common pulmonary disease, mainly characterized by irreversible airway flow limitations [22]. The GBD 2016 showed that there were approximately 251.6 million patients suffering from COPD thus far, and COPD has become one of the leading causes of global deaths [23]. With increasing evidences to support the adverse effect of PM10 or PM2.5 on the patients with COPD, PM is considered to be an important risk factor for COPD. Now, short-term (hours, days) or longterm (months, years) exposure to PM are the two different exposure metrics to evaluate the health effect of PM on the patients with COPD.

The short-term exposure to PM could exacerbate the disease process of COPD. Several meta-analysis have confirmed that PM10 or PM2.5 with a $10 \mu \mathrm{g} / \mathrm{m}^{3}$ increase in concentration could lead to a decrease in forced vital capacity (FVC), forced expiratory volume during the first second $\left(\mathrm{FEV}_{1}\right), \mathrm{FEV}_{1} / \mathrm{FVC}$ ratio and peak expiratory flow (PEF) [24,25]. PM2.5 even showed a stronger harm on the lung function of COPD patients than PM10. One possible reason is that the PM2.5 with smaller size are easier to be inhaled into the small airways and the alveoli of the lung. Two successive meta-analysis studies showed that a $10 \mu \mathrm{g} / \mathrm{m}^{3}$ increase in PM2.5 could contribute to a $3.1 \%$ (95\% CI: $1.6 \%$ to $4.6 \%$ ) increase in COPD-related HAs and a $2.5 \%$ (95\% CI: $1.5 \%$ to $3.5 \%$ ) increase in COPD mortality, and a $2.5 \%(95 \%$ CI: $1.6 \%$ to $3.4 \%$ ) increase in the risk of COPD-related $\mathrm{ED}$ visits and HAs [26,27]. As for PM10, Zhu et al. showed that a $10 \mu \mathrm{g} / \mathrm{m}^{3}$ increase in PM10 was associated with a $2.7 \%$ (95\% CI: $1.9 \%$ to $3.6 \%)$ increase in COPD-related HAs and a $1.1 \%$ (95\% CI: $0.8 \%$ to $1.4 \%)$ increase in COPD mortality [28].

However, evidences about association between long-term PM exposure and patients with COPD were limited. Four cohorts from the European Study of Cohorts for Air Pollution Effects (ESCAPE) were included to assess the impact of PM on the prevalence and incidence of COPD which was defined according to $\mathrm{FEV}_{1} / \mathrm{FVC}$ and the GOLD criterion, but no statistically significant associations between PM and COPD morbidity were defined [29]. Similar results were acquired

\begin{tabular}{|c|c|c|c|c|c|c|}
\hline Disease & Age & $\begin{array}{c}\mathrm{PM}(\boldsymbol{\mu} \mathrm{g} / \\
\left.\mathrm{m}^{3}\right)\end{array}$ & $\begin{array}{c}\text { Exposure } \\
\text { time }\end{array}$ & $\begin{array}{c}\text { Evaluation } \\
\text { index }\end{array}$ & \begin{tabular}{|c|} 
RR/OR \\
(95\% Cl)
\end{tabular} & Reference \\
\hline \multirow{2}{*}{ COPD } & \multirow{2}{*}{-} & \multirow{2}{*}{$\begin{array}{c}\text { PM2.5 } \\
(10 \mu \mathrm{g} / \\
\left.\mathrm{m}^{3}\right)\end{array}$} & $\begin{array}{l}\text { multi-day } \\
\text { averages }\end{array}$ & \multirow{2}{*}{$\begin{array}{l}\text { ED visits } \\
\text { and } H A s\end{array}$} & $\begin{array}{c}1.03(95 \% \\
\text { Cl } 1.02- \\
1.03)\end{array}$ & \multirow{2}{*}{$\begin{array}{l}\text { DeVries et } \\
\text { al. [26] }\end{array}$} \\
\hline & & & $\begin{array}{l}\text { single-day } \\
\text { lags }\end{array}$ & & $\begin{array}{c}1.01(95 \% \\
\text { Cl 1.01- } \\
1.02)\end{array}$ & \\
\hline \multirow{2}{*}{ COPD } & \multirow{2}{*}{-} & \multirow{2}{*}{$\begin{array}{c}\text { PM2.5 } \\
(10 \mu \mathrm{g} / \\
\left.\mathrm{m}^{3}\right)\end{array}$} & \multirow{2}{*}{$\begin{array}{c}\text { lag days } \\
0-7\end{array}$} & HAs & $\begin{array}{c}1.03(95 \% \\
\text { Cl 1.02- } \\
1.05)\end{array}$ & \multirow{2}{*}{ Li et al. [27] } \\
\hline & & & & mortality & $\begin{array}{c}1.03(95 \% \\
\text { Cl } 1.02 \\
-1.04)\end{array}$ & \\
\hline \multirow{2}{*}{ COPD } & - & $\begin{array}{c}\text { PM10 } \\
(10 \mu \mathrm{g} / \\
\left.\mathrm{m}^{3}\right)\end{array}$ & $\begin{array}{c}\text { lag days } \\
0-7\end{array}$ & HAs & $\begin{array}{c}1.03(95 \% \\
\text { Cl 1.02- } \\
1.04)\end{array}$ & \multirow{2}{*}{$\begin{array}{c}\text { Zhu et al. } \\
\text { [28] }\end{array}$} \\
\hline & & & & mortality & $\begin{array}{c}1.01(95 \% \\
\text { Cl } 1.01 \\
-1.01)\end{array}$ & \\
\hline \multirow{2}{*}{ Asthma } & \multirow{2}{*}{$\begin{array}{l}\text { under } \\
18 \\
\text { years } \\
\text { old }\end{array}$} & $\begin{array}{c}\mathrm{PM} 2.5(1 \\
\left.\mu \mathrm{g} / \mathrm{m}^{3}\right)\end{array}$ & \multirow{2}{*}{-} & \multirow{2}{*}{ incidence } & $\begin{array}{c}1.03(95 \% \\
\text { Cl 1.01- } \\
1.05)\end{array}$ & \multirow{2}{*}{$\begin{array}{l}\text { Khreis et } \\
\text { al. [34] }\end{array}$} \\
\hline & & $\begin{array}{l}\mathrm{PM} 10(2 \\
\left.\mu \mathrm{g} / \mathrm{m}^{3}\right)\end{array}$ & & & $\begin{array}{c}1.05(95 \% \\
\mathrm{Cl} 1.02- \\
1.08)\end{array}$ & \\
\hline Asthma & $\begin{array}{l}\text { under } \\
20 \\
\text { years } \\
\text { old }\end{array}$ & $\begin{array}{c}\mathrm{PM} 2.5 \\
(10 \mu \mathrm{g} / \\
\left.\mathrm{m}^{3}\right)\end{array}$ & short-term & $\begin{array}{l}\text { ED visits } \\
\text { and HAs }\end{array}$ & $\begin{array}{c}1.05(95 \% \\
\text { Cl } 1.03- \\
1.07)\end{array}$ & $\begin{array}{l}\text { Lim et al. } \\
\text { [37] }\end{array}$ \\
\hline Asthma & - & $\begin{array}{c}\text { PM2.5 } \\
(10 \mu \mathrm{g} / \\
\left.\mathrm{m}^{3}\right)\end{array}$ & short-term & ED visits & $\begin{array}{c}1.02(95 \% \\
\mathrm{Cl} 1.02- \\
1.02)\end{array}$ & $\begin{array}{c}\text { Fan et al. } \\
\text { [39] }\end{array}$ \\
\hline \multirow{2}{*}{ Asthma } & \multirow{2}{*}{-} & $\begin{array}{c}\text { PM2.5 } \\
(10 \mu \mathrm{g} / \\
\left.\mathrm{m}^{3}\right)\end{array}$ & \multirow{2}{*}{ lag day 1} & \multirow{2}{*}{$\begin{array}{l}\text { ED visits } \\
\text { and HAs }\end{array}$} & $\begin{array}{c}1.02(95 \% \\
\text { Cl 1.02- } \\
1.03)\end{array}$ & \multirow{2}{*}{$\begin{array}{l}\text { Zheng et } \\
\text { al. [38] }\end{array}$} \\
\hline & & $\begin{array}{c}\text { PM10 } \\
(10 \mu \mathrm{g} / \\
\left.\mathrm{m}^{3}\right)\end{array}$ & & & $\begin{array}{c}1.01(95 \% \\
\text { Cl 1.01- } \\
1.01)\end{array}$ & \\
\hline \multirow{4}{*}{ Lung cancer } & \multirow{4}{*}{ - } & \multirow{2}{*}{$\begin{array}{c}\text { PM2.5 } \\
(10 \mu \mathrm{g} / \\
\left.\mathrm{m}^{3}\right)\end{array}$} & \multirow{4}{*}{ - } & incidence & $\begin{array}{c}1.03(95 \% \\
\text { Cl } 0.48- \\
1.58)\end{array}$ & \multirow{4}{*}{$\begin{array}{l}\text { Cui et al. } \\
\text { [43] }\end{array}$} \\
\hline & & & & mortality & $\begin{array}{c}1.09(95 \% \\
\text { Cl 1.06- } \\
1.11)\end{array}$ & \\
\hline & & \multirow{2}{*}{$\begin{array}{l}\text { PM10 } \\
(10 \mu \mathrm{g} / \\
\left.\mathrm{m}^{3}\right)\end{array}$} & & incidence & $\begin{array}{c}1.45(95 \% \\
\mathrm{Cl} 0.87- \\
2.03)\end{array}$ & \\
\hline & & & & mortality & $\begin{array}{c}1.05(95 \% \\
\text { Cl 1.03- } \\
1.07)\end{array}$ & \\
\hline \multirow{2}{*}{ Lung cancer } & \multirow{2}{*}{-} & $\begin{array}{c}\text { PM2.5 } \\
(10 \mu \mathrm{g} / \\
\left.\mathrm{m}^{3}\right)\end{array}$ & \multirow{2}{*}{ - } & \multirow{2}{*}{$\begin{array}{l}\text { incidence } \\
\text { and } \\
\text { mortality }\end{array}$} & $\begin{array}{c}1.09(95 \% \\
\text { Cl } 1.04- \\
1.14)\end{array}$ & \multirow{2}{*}{$\begin{array}{c}\text { Hamra et } \\
\text { al. [46] }\end{array}$} \\
\hline & & $\begin{array}{c}\text { PM10 } \\
(10 \mu \mathrm{g} / \\
\left.\mathrm{m}^{3}\right)\end{array}$ & & & $\begin{array}{c}1.08(95 \% \\
\text { Cl } 1.00- \\
1.17)\end{array}$ & \\
\hline Lung cancer & - & $\begin{array}{c}\text { PM2.5 } \\
(10 \mu \mathrm{g} / \\
\left.\mathrm{m}^{3}\right)\end{array}$ & - & incidence & $\begin{array}{c}1.11(95 \% \\
\mathrm{Cl} 1.00- \\
1.22)\end{array}$ & $\begin{array}{c}\text { Chen et al. } \\
\text { [85] }\end{array}$ \\
\hline \multirow{2}{*}{ Pneumonia } & \multirow{2}{*}{$\begin{array}{l}\text { under } \\
18 \\
\text { years } \\
\text { old }\end{array}$} & $\begin{array}{c}\text { PM2.5 } \\
(10 \mu \mathrm{g} / \\
\left.\mathrm{m}^{3}\right)\end{array}$ & & & $\begin{array}{c}1.02(95 \% \\
\text { Cl 1.01- } \\
1.03)\end{array}$ & Nhung et \\
\hline & & $\begin{array}{l}\text { PM10 } \\
(10 \mu \mathrm{g} / \\
\left.\mathrm{m}^{3}\right)\end{array}$ & short-term & ED visits & $\begin{array}{c}1.02(95 \% \\
\mathrm{Cl} 1.01- \\
1.02)\end{array}$ & al. [56] \\
\hline
\end{tabular}

Table 1: A summary of meta-analysis on the association between PM exposure and respiratory diseases (COPD, asthma, lung cancer and pneumonia).

according to the data from a nationally representative cohort in England [30]. These inconclusive results might be due to differences in 
study design, definition of COPD, exposure assessment and statistical methods. However, significant association of chronic PM exposure with COPD was identified in some specific subgroups. For example, Kariisa et al. found that long-term PM2.5 exposure significantly decreased lung function and increased respiratory symptoms in 1218 severe COPD patients [31]. Pun et al. showed that long-term PM2.5 exposure could lead to a $10 \%$ increased risks of COPD mortality in older US adults [20].

\section{PM and Asthma}

It is estimated that asthma affects more than 300 million people around the world. In 2010, it ranked as the $28^{\text {th }}$ highest cause of disabilityadjusted life years worldwide [32,33]. Asthma can appear at any age and has the highest prevalence in children and young adults [32]. As for the immature defense function of respiratory system, children exposed to PM are more likely to develop asthma. A recent meta-analysis reviewed 41 epidemiological studies about the association between PM exposure and the risk of asthma incidence or lifetime prevalence in childhood aged from 1 to 18 years, and found that PM10 or PM2.5 exposure was a risk factor for the development of asthma in children. The overall random-effects risk estimates for asthma development were 1.05 (95\% CI: 1.02 to 1.08 ) per $2 \mu \mathrm{g} / \mathrm{m}^{3}$ PM10 and 1.03 (95\% CI: 1.01 to 1.05 ) per 1 $\mu \mathrm{g} / \mathrm{m}^{3} \mathrm{PM} 2.5$, respectively [34]. Further, another meta-analysis showed that prenatal exposure to PM10 could increase the risk of wheezing and asthma development in childhood aged 0 to 10 years $(\mathrm{OR}=1.08 ; 95 \%$ CI: 1.05 to 1.12), but non-significant effect of prenatal PM2.5 exposure on children asthma (OR=1.4; 95\% CI: 0.97 to 2.03) [35]. However, the effect of PM on incidence of asthma remains elusive in adults. PM 10 and PM2.5 showed a positive, but not significant, association with the incidence of adult asthma in six European cohorts [36]. The diagnosis bias, population heterogeneity and exposure assessment limited this result, and further studies were needed to elucidate the association between PM and adult asthma incidence.

Recently, the effect of PM on the exacerbation of asthma, including ED visits and HAs, was well-defined in both children and adults. For children, a recent meta-analysis showed that a short-term $10 \mu \mathrm{g} / \mathrm{m}^{3}$ increase in PM2.5 increased children's ED visits and HAs due to asthma ( $\mathrm{RR}=1.048 ; 95 \% \mathrm{CI}: 1.028$ to 1.067$)$ [37]. In another meta-analysis, a positive association between asthma-related $\mathrm{ED}$ visits and HAs and exposure to PM10 (RR=1.010; 95\% CI: 1.008 to 1.013 per $10 \mu \mathrm{g} / \mathrm{m}^{3}$ ) or PM2.5 (RR=1.023; 95\% CI: 1.015 to 1.031 per $10 \mu \mathrm{g} / \mathrm{m}^{3}$ ) was defined in children and adults. Further, the subgroup analysis found that three factors (male, children and warm season) could make association stronger [38]. Similar conclusions were drawn in a meta-analysis that evaluated the asthma-related ED visits and PM2.5 exposure in children and adults [39]. Thus, PM exposure led to an adverse impact on the exacerbation of asthma, especially in children and in warm season.

\section{PM and Lung Cancer}

Lung cancer is a multi-factorial cancer with poor prognosis and causes large disease burden worldwide. In 2015, it was estimated that the global morbidity and mortality of lung cancer were 2 million and 1.7 million, respectively [40]. The International Agency for Research on Cancer (IARC) has classified outdoor air pollution and PM as proven carcinogens for humans [41]. The effect of long-term PM exposure on lung cancer focused on incidence and mortality of lung cancer.

There were still some conflicts about the association between $\mathrm{PM}$ and the incidence of lung cancer. In one meta-analysis reviewing six studies, PM2.5 in traffic-related air pollution showed positive association with the lung cancer incidence $(\mathrm{OR}=1.11 ; 95 \% \mathrm{CI}: 1.00$ to 1.22 per $10 \mu \mathrm{g} / \mathrm{m}^{3}$ ) [42]. Paradoxically, no significant association between PM and lung cancer incidence was identified in another metaanalysis, which only included three studies for PM10 and two studies for PM2.5 [43]. The limited number of studies for meta-analysis and the different selection criteria make these results inconsistent, and thus more studies are needed to address the association between PM and lung cancer incidence. However, the ESCAPE conducted a subgroup analysis according to histological cancer subtype and found that both PM10 and PM2.5 significantly contributed to adenocarcinomas of the lung [44]. Further, the effect of PM components on lung cancer incidence was identified in a European study. They compared eight elements (copper $(\mathrm{Cu})$, iron $(\mathrm{Fe})$, potassium $(\mathrm{K})$, nickel $(\mathrm{Ni})$, sulfur $(\mathrm{S})$, silicon $(\mathrm{Si})$, vanadium $(\mathrm{V})$ and zinc $(\mathrm{Zn}))$ in PM10 and PM2.5, and found that $\mathrm{Cu}$ from PM2.5 and $\mathrm{Zn}, \mathrm{S}, \mathrm{Ni}$ and $\mathrm{K}$ from $\mathrm{PM} 10$ had positive associations with the incidence of lung cancer [45].

However, the effect of PM on the lung cancer mortality is well defined. Recently, several meta-analysis have demonstrated that both PM2.5 and PM10 contributed to increasing lung cancer mortality $[43,46,47]$. The relative risk for lung cancer mortality were $1.09(95 \%$ CI: 1.06 to 1.11 ) for PM2.5 per $10 \mu \mathrm{g} / \mathrm{m}^{3}$, and 1.05 (95\% CI: 1.03 to 1.07) for PM10 per $10 \mu \mathrm{g} / \mathrm{m}^{3}$ [43]. Smoking is an important risk factor for lung cancer and is considered to confound the estimates for associations between PM and lung cancer mortality. One subgroup analysis according to smoking status found that former smokers had the greatest lung cancer risk associated with PM2.5, followed by never-smokers and current smokers [46]. Besides, the adverse effect of PM10 on lung cancer mortality strengthened in second-hand smokers, compared with never smokers [48]. Thus, smoking status should be included to analyse the association between PM and lung cancer in further studies.

\section{PM and Pneumonia}

Pneumonia is a common respiratory disease that can be caused by bacteria, viruses, or fungi. The morbidity and mortality of pneumonia vary with age, geographic region, and population at risk among other factors [49]. Recently, most of epidemiological studies have supported the evidence that PM had a positive association with morbidity (ED visits and HAs) and motility of pneumonia. The study from Atlanta showed that a short-term PM10 and PM2.5 exposure were associated with 1\%-3\% increase in ED visits due to upper respiratory infection and pneumonia [50]. Moreover, another two studies from different countries have demonstrated an increase in HAs for pneumonia with PM10 levels [51,52]. Further, PM10 had a more marked effect with an increase of $1.47 \%$ (95\% CI: $0.93 \%$ to $2.01 \%$ ) in pneumonia-related HA during the warm season [52]. Besides, in a study from Hong Kong, PM2.5 caused a $0.67 \%$ ( $95 \%$ CI: $0.14 \%$ to $1.21 \%$ per $\left.10 \mu \mathrm{g} / \mathrm{m}^{3}\right)$ increase in mortality due to pneumonia in daily mean concentration at lag 2 day [53]. However, the study from a Chinese city showed that there was no significant effect of PM on the morbidity of pneumonia [54]. Thus, further studies should cover more different areas, make exposure assessment harmonization and include confounding factors to make the results consistent.

The elderly, children under five years of age, and those with special comorbidities are more susceptible to pneumonia [55]. The adverse effect of PM on pneumonia incidence and pneumonia-related ED visits and HAs among these special individuals was analyzed. A latest meta-analysis showed that short-term PM10 and PM2.5 exposure increased the ED visits in children under five years old $(1.5 \%(95 \%$ CI: $0.6 \%$ to $2.4 \%$ ) for PM10 per $10 \mu \mathrm{g} / \mathrm{m}^{3}$ and $1.8 \%$ (95\% CI: $0.5 \%$ to $3.1 \%$ ) for PM2.5 per $10 \mu \mathrm{g} / \mathrm{m}^{3}$ ) [56]. The positive association between 
PM exposure and pneumonia-related HAs was also identified in older adults or children $[57,58]$. However, the ESCAPE Project showed that PM10, but not PM2.5, had a statistically significant association with pneumonia incidence in early children $(\mathrm{OR}=1.76 ; 95 \% \mathrm{CI}: 1.00$ to 3.09 per $10 \mu \mathrm{g} / \mathrm{m}^{3}$ ) [59]. More interesting, only $\mathrm{Zn}$ from PM10 was independently associated with the early-life pneumonia incidence in children [60].

\section{The Potential Biological Mechanism}

The toxic effect of PM is complicated and different mechanisms have been proposed to explain the adverse effect of PM on respiratory diseases, such as COPD, asthma, lung cancer and pneumonia. The PM enters and deposits in the lung with breathing to directly or indirectly cause the oxidant stress, pro-inflammation, epigenetic modifications, apoptosis, DNA damage and even carcinogenesis in the lung cells. These biological dysfunctions contribute to the increasing morbidity and mortality of respiratory diseases (Figure 1).

\section{Oxidant Stress and Pro-Inflammation}

The cellular redox equilibrium is essential in maintaining normal biological process. Under physical condition, cells produce a variety of antioxidants to neutralize the reactive oxygen species (ROS) and oxygen radicals [61]. However, exogenous and endogenous stimuli often disturb the balance between oxidation and anti-oxidation and make excessive ROS accumulation to form oxidant stress. Oxidant stress has been demonstrated as an important mechanism in PMinduced respiratory diseases and excessive ROS acts as a key mediator to initiate pro-inflammation, physical barrier disruption, cell death and carcinogensis [62]. There is accumulating evidence that PM can induce the ROS generation in vitro and in vivo. Bronchial epithelial cells, macrophages and neutrophils, as the main targets of PM in the lung, can generate ROS with the stimulation of PM in vitro [63-65]. Our study also found that urban dust $1649 \mathrm{~b}$ could increase the generation of ROS in a time- and dose-dependent manner significantly [66]. Li et al. compared the oxidant stress responses for particles in different cells and found that bronchial epithelial cells generated more superoxide radicals and were more susceptible to cytotoxic effects than macrophages [67]. The animal studies also showed that intratracheal administration of PM could markedly elevate the ROS levels in the lung tissue. The high level

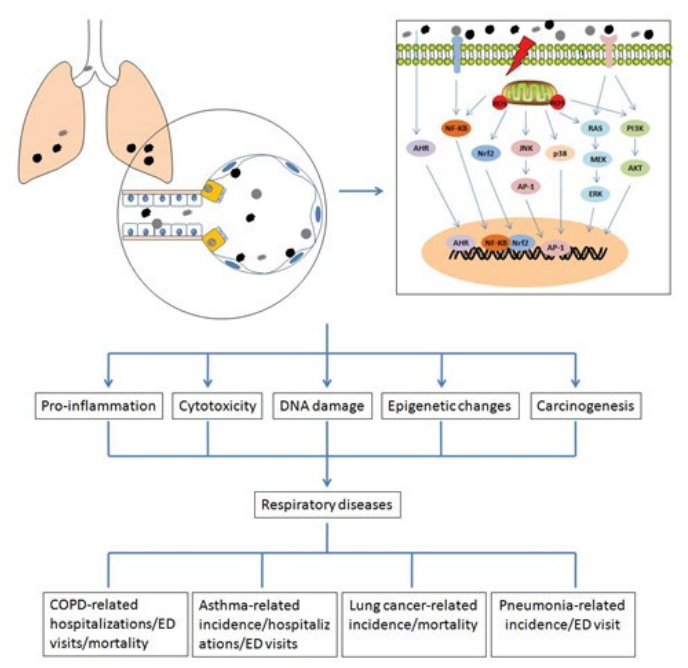

Figure 1: The potential mechanism for the effect of PM on the morbidity and mortality of respiratory diseases. of ROS could increase neutrophils infiltration in the lung tissue and activate neutrophils to produce more ROS. In addition, pretreatment with antioxidant $\mathrm{N}$-acetylcysteine could attenuate the PM-induced lung inflammation [68-70]. However, no direct evidences have been found that PM could increase the ROS production in human lung tissue.

Inflammatory responses for PM are a universal biological process in different lung cells. Numerous studies have showed that oxidant stress could activate intracellular different signaling pathways to promote PM-induced inflammatory pathogenesis in vitro and in vivo [71]. The transcriptional activation of cytokines, chemokines and adhesion molecules played an important role in PM-induced lung inflammation. Our study found that urban dust $1649 \mathrm{~b}$ could induce the expression of pro-inflammatory mediators IL- $1 \beta$, IL-6, IL-8, MMP-9 and COX-2 via ROS-MAPK-NF- $\mathrm{KB}$ signaling pathway in bronchial epithelial cells [66]. However, the compositions of PM determine differential inflammatory responses in the lung. Jeong et al. used two different methods to obtain water-soluble (W-PM2.5) and organic-soluble (O-PM2.5) from PM2.5 samples and the cytokine antibody array revealed differential cytokines expression in human alveolar epithelial cells with exposure to W-PM2.5 or O-PM2.5, respectively [72]. The animal models also showed a different response to W-PM2.5 or O-PM2.5, especially with regard to IL-8 expression. In an asthmatic mice study, acute exposure of PM2.5 greatly increased the expression of pro-inflammatory cytokines and Th2-related cytokines, and aggravated the severity of asthma [73]. Similarly, PM2.5 exposure promoted the production of proinflammatory cytokines (IL-6, IL-8 and TNF- $\alpha$ ) and aggravated lung tissue damage in COPD mice model [74]. In addition, inflammatory responses disturb the microenvironmental homeostasis to promote the development and progression of lung cancer.

\section{Cytotoxicity and Carcinogenesis}

Cell death is another mechanism for PM-induced respiratory diseases. The oxidative stress, inflammation-related cascades and DNA damage are considered to participate into PM-induced cell death [75]. Recently, different cell death types (apoptosis, autophagy and necrosis) have been demonstrated to be associated with PM exposure in lung cells. Deng et al. found that PM2.5 could activate extrinsic and intrinsic apoptosis pathway and increase autophagy in A549 cells [76]. p53, as an important tumor suppressor, was activated by PM to mediate mitochondrial dysfunction, which was the result of regulating Bcl-2/Bax ratio, to induce PM-induced apoptosis [77]. In addition, Zhou et al. showed that high dose of PM2.5 exposure contributed to cell necrosis and autophagy [78]. The components of PM often affect the cytotoxicity of PM. Schiliro et al. showed that water-soluble PM inhibited cell proliferation more strongly than organic-soluble PM [79]. The polycyclic aromatic hydrocarbons (PAHs) in organic-soluble PM are apt to permeate into cells and disrupt the structure of DNA to cause DNA damage [75]. However, some studies showed that PM had no proapoptotic effect on lung cells. The aryl hydrocarbon receptor (AHR)related pathway was activated by PAHs in PM to induce the expression of anti-apoptotic genes Bcl-2 and Bcl-2L1 [80].

PM could promote the carcinogenesis by inducing DNA damage and genomic instability. Hornberg et al. found that sister chromatid exchange was induced in bronchial epithelial cells when exposed to PM10 and PM2.5 [81]. The PAHs in PM could directly act on the DNA to form DNA adduct and abasic sites [82]. Yu et al. found that PM exposure contributed to somatic mutations in lung cancer and several gene mutations had a positive association with benzo[a]pyrene $(\mathrm{BaP})$ exposure [83]. In addition, PM-induced oxidant stress, DNA damage and gene expression alternation for cell-cycle checkpoint disturbed cell- 
cycle progression at different phages to induce genetic instability [80]. Cancer is multi-factorial disease and the mechanism of PM-induced carcinogenesis also remains unclear.

\section{Epigenetic Changes}

The PM-induced epigenetic changes focus on DNA methylation and histone modification [70]. Baccarelli et al. found that PM exposure caused a decrease in repeated-element methylation [84]. Chen et al. showed that PM2.5 exposure decreased the NOS2A DNA methylation and increased FeNO in COPD patients [85]. Several studies also showed that PM could affect histone modification. The effect of different exposure level of PM2.5 on histone 3 lysine 27 acetylation (H3K27ac) was revealed by using the genome-wide chromatin immunoprecipitation sequencing (ChIP-Seq) and there was a global elevation of the enhancer-associated H3K27ac markers in individuals exposed to high level of PM2.5 [86]. Besides, the H3K9 acetylation was found to increase in both peripheral blood mononuclear cells (PBMCs) and lung tissues of rat with PM2.5 or PM10 exposure [87].

\section{Conclusion}

There are strong epidemiological evidences to support the adverse effect of PM exposure on the morbidity and mortality of respiratory diseases, including COPD, asthma, lung cancer and pneumonia. Thus, effective interventions to reduce PM exposure can help to decrease the risk of respiratory diseases. Guan et al. proposed several substantial measures including novel medications, industrial upgrading, renovation of vehicle fuel and public transportation, incorporation of PM2.5 levels in weather forecasts, improving cooking fuel and ventilation, implementing environmental policies and building up healthy cities [88]. At a personal level, wearing face masks outdoors, using air filters indoors and smoking cessation are efficient methods to reduce PM exposure and decrease PM-related respiratory diseases in the public $[88,89]$. With the increasing understanding of PM on respiratory diseases, there will be more efficient interventions to alleviate the PMinduced health burden.

\section{Acknowledgement}

This research was supported by the State Key Basic Research Program (973) project (2015CB553404), Doctoral Fund of Ministry of Education of China (20130071110044), Shanghai Science and Technology Committee (15DZ1930600/15DZ1930602), Shanghai Municipal Commission of Health and Family Planning (201540370), the National Natural Science Foundation of China (81490533, 81500026, 81630001 and 81770055).

\section{Competing Interest}

The authors declare that they have no competing interests. Wang $\mathrm{J}$ and Chen $\mathrm{S}$ have contributed equally to this work.

\section{References}

1. World Health Organization (2016) Ambient air pollution: A global assessment of exposure and burden of disease. Geneva.

2. GBD 2016 Risk Factors Collaborators (2017) Global, regional, and national comparative risk assessment of 84 behavioural, environmental and occupational, and metabolic risks or clusters of risks, 1990-2016: A systematic analysis for the Global Burden of Disease Study 2016. Lancet 390: 1345-1422.

3. Global Health Data Exchange (2017) Institute for Health Metrics and Evaluation.

4. Song C, He J, Wu L, Jin T and Chen X, et al. (2017) Health burden attributable to ambient PM 2.5 in China. Environ Pollut 223: 575-586.

5. Burnett RT, Pope CR, Ezzati M, Olives C, Lim SS, et al. (2014) An integrated risk function for estimating the global burden of disease attributable to ambient fine particulate matter exposure. Environ Health Perspect 122: 397-403.

6. Fiordelisi A, Piscitelli P, Trimarco B, Coscioni E, laccarino G, et al. (2017) The mechanisms of air pollution and particulate matter in cardiovascular diseases.
Heart Fail Rev 22: 337-347.

7. Huang YC (2014) Outdoor air pollution: A global perspective. J Occup Environ Med 56: S3-S7.

8. DeFranco E, Moravec W, Xu F, Hall E, Hossain M, et al. (2016) Exposure to airborne particulate matter during pregnancy is associated with preterm birth: $A$ population-based cohort study. Environ Health 15: 6.

9. Chen H, Burnett RT, Kwong JC, Villeneuve PJ, Goldberg MS, et al. (2013) Risk of incident diabetes in relation to long-term exposure to fine particulate matter in Ontario, Canada. Environ Health Perspect 121: 804-810.

10. Feng S, Gao D, Liao F, Zhou F, Wang X (2016) The health effects of ambient PM 2.5 and potential mechanisms. Ecotoxicol Environ Saf 128: 67-74.

11. Churg A, Brauer M (1997) Human lung parenchyma retains PM2.5. Am J Respir Crit Care Med 155: 2109-2111.

12. Crouse DL, Philip S, van Donkelaar A, Martin RV, Jessiman B, et al. (2016) A new method to jointly estimate the mortality risk of long-term exposure to fine particulate matter and its components. Sci Rep 6: 18916.

13. Bari MA, Kindzierski WB (2017) Ambient fine particulate matter (PM2.5) in Canadian oil sands communities: Levels, sources and potential human health risk. Sci Total Environ 595: 828-838.

14. Gautam S, Yadav A, Tsai CJ, Kumar P (2016) A review on recent progress in observations, sources, classification and regulations of PM2.5 in Asian environments. Environ Sci Pollut Res Int 23: 21165-21175.

15. World Health Organization (2005) WHO Air quality guidelines for particulate matter, ozone, nitrogen dioxide and sulfur dioxide.

16. Conti S, Lafranconi A, Zanobetti A, Cesana G, Madotto F, et al. (2017) The short-term effect of particulate matter on cardiorespiratory drug prescription, as a proxy of mild adverse events. Environ Res 157: 145-152.

17. Zeng Q, Wu Z, Jiang G, Wu X, Li P, et al. (2017) The association between ambient inhalable particulate matter and the disease burden of respiratory disease: An ecological study based on ten-year time series data in Tianjin China. Environ Res 157: 71-77.

18. Atkinson RW, Mills IC, Walton HA, Anderson HR (2015) Fine particle components and health: A systematic review and meta-analysis of epidemiological time series studies of daily mortality and hospital admissions. J Expo Sci Environ Epidemiol 25: 208-214

19. Atkinson RW, Kang S, Anderson HR, Mills IC, Walton HA (2014) Epidemiological time series studies of PM2.5 and daily mortality and hospital admissions: A systematic review and meta-analysis. Thorax 69: 660-665.

20. Pun VC, Kazemiparkouhi F, Manjourides J, Suh HH (2017) Long-term PM2.5 exposures and respiratory, cancer and cardiovascular mortality in American older adults. Am J Epidemiol 186: 961-969.

21. Chen R, Yin P, Meng X, Liu C, Wang L, et al. (2017) Fine particulate air pollution and daily mortality. A nationwide analysis in 272 chinese cities. Am J Respir Crit Care Med 196: 73-81.

22. Rabe KF, Watz H (2017) Chronic obstructive pulmonary disease. Lancet 389 : 1931-1940.

23. GBD 2016 Disease and Injury Incidence and Prevalence Collaborators (2017) Global, regional, and national incidence, prevalence, and years lived with disability for 328 diseases and injuries for 195 countries, 1990-2016: A systematic analysis for the Global Burden of Disease Study 2016. Lancet 390: 1211-1259.

24. Bloemsma LD, Hoek G and Smit LA (2016) Panel studies of air pollution in patients with COPD: Systematic review and meta-analysis. Environ Res 151: 458-468.

25. Liu S, Zhou Y, Liu S, Chen X and Zou W, et al. (2016) Association between exposure to ambient particulate matter and chronic obstructive pulmonary disease: results from a cross-sectional study in China. Thorax 72: 788-795.

26. DeVries R, Kriebel D and Sama S (2017) Outdoor Air Pollution and COPDRelated Emergency Department Visits, Hospital Admissions, and Mortality: A Meta-Analysis. Copd 14: 113-121.

27. Li MH, Fan LC, Mao B, Yang JW and Choi AM, et al. (2016) Short-term Exposure to Ambient Fine Particulate Matter Increases Hospitalizations and Mortality in COPD: A Systematic Review and Meta-analysis. Chest 149: 447-458.

28. Zhu R, Chen Y, Wu S, Deng F and Liu Y, et al. (2013) The relationship between 
particulate matter (PM10) and hospitalizations and mortality of chronic obstructive pulmonary disease: a meta-analysis. Copd 10: 307-315.

29. Schikowski T, Adam M, Marcon A, Cai Y and Vierkotter A, et al. (2014) Association of ambient air pollution with the prevalence and incidence of COPD. Eur Respir J 44: 614-626.

30. Atkinson RW, Carey IM, Kent AJ, van Staa TP and Anderson HR, et al. (2015) Long-term exposure to outdoor air pollution and the incidence of chronic obstructive pulmonary disease in a national English cohort. Occup Environ Med 72: $42-48$

31. Kariisa M, Foraker R, Pennell M, Buckley T and Diaz P, et al. (2015) Short- and long-term effects of ambient ozone and fine particulate matter on the respiratory health of chronic obstructive pulmonary disease subjects. Arch Environ Occup Health 70: 56-62.

32. Backman H, Raisanen $\mathrm{P}$, Hedman L, Stridsman $\mathrm{C}$ and Andersson M, et al (2017) Increased prevalence of allergic asthma from 1996 to 2006 and further to 2016-results from three population surveys. Clin Exp Allergy 47: 1426-1425.

33. Murray CJ, Vos T, Lozano R, Naghavi M and Flaxman AD, et al. (2012) Disability-adjusted life years (DALYs) for 291 diseases and injuries in 21 regions, 1990-2010: a systematic analysis for the Global Burden of Disease Study 2010. Lancet 380: 2197-2223.

34. Khreis H, Kelly C, Tate J, Parslow R, Lucas K, et al. (2017) Exposure to trafficrelated air pollution and risk of development of childhood asthma: A systematic review and meta-analysis. Environ Int 100: 1-31.

35. Hehua Z, Qing C, Shanyan G, Qijun W, Yuhong Z (2017) The impact of prenatal exposure to air pollution on childhood wheezing and asthma: A systematic review. Environ Res 159: 519-530.

36. Jacquemin B, Siroux V, Sanchez M, Carsin AE, Schikowski T, et al. (2015) Ambient air pollution and adult asthma incidence in six European cohorts (ESCAPE). Environ Health Perspect 123: 613-621.

37. Lim H, Kwon HJ, Lim JA, Choi JH, Ha M, et al. (2016) Short-term Effect of Fine Particulate Matter on Children's Hospital Admissions and Emergency Department Visits for Asthma: A Systematic Review and Meta-analysis. J Prev Med Public Health 49: 205-219.

38. Zheng XY, Ding H, Jiang LN, Chen SW, Zheng JP, et al. (2015) Association between Air Pollutants and Asthma Emergency Room Visits and Hospital Admissions in Time Series Studies: A Systematic Review and Meta-Analysis. Plos One 10: e0138146.

39. Fan J, Li S, Fan C, Bai Z, Yang K (2016) The impact of PM2.5 on asthma emergency department visits: A systematic review and meta-analysis. Environ Sci Pollut Res Int 23: 843-850.

40. Fitzmaurice C, Allen C, Barber RM, Barregard L, Bhutta ZA, et al. (2017) Global, Regional, and National Cancer Incidence, Mortality, Years of Life Lost, Years Lived With Disability, and Disability-Adjusted Life-years for 32 Cance Groups, 1990 to 2015: A Systematic Analysis for the Global Burden of Disease Study. Jama Oncol 3: 524-548.

41. IARC (2016) International Agency for Research on Cancer (IARC) monographs on the evaluation of carcinogenic risks to humans: Outdoor air pollution.

42. Chen G, Wan X, Yang G, Zou X (2015) Traffic-related air pollution and lung cancer: A meta-analysis. Thorac Cancer 6: 307-318.

43. Cui P, Huang Y, Han J, Song F, Chen K (2015) Ambient particulate matter and lung cancer incidence and mortality: a meta-analysis of prospective studies. Eur J Public Health 25: 324-329.

44. Raaschou-Nielsen O, Andersen ZJ, Beelen R, Samoli E, Stafoggia M, et al. (2013) Air pollution and lung cancer incidence in 17 European cohorts: prospective analyses from the European Study of Cohorts for Air Pollution Effects (ESCAPE). Lancet Oncol 14: 813-822.

45. Raaschou-Nielsen O, Beelen R, Wang M, Hoek G, Andersen ZJ, et al. (2016) Particulate matter air pollution components and risk for lung cancer. Environ Int 87: 66-73.

46. Hamra GB, Guha N, Cohen A, Laden F, Raaschou-Nielsen O, et al. (2014) Outdoor particulate matter exposure and lung cancer: a systematic review and meta-analysis. Environ Health Perspect 122: 906-911.

47. Chen H, Goldberg MS, Villeneuve PJ (2008) A systematic review of the relation between long-term exposure to ambient air pollution and chronic diseases. Rev Environ Health 23: 243-297.

48. Chen X, Zhang LW, Huang JJ, Song FJ, Zhang LP, et al. (2016) Long- term exposure to urban air pollution and lung cancer mortality: A 12-year cohort study in Northern China. Sci Total Environ 571: 855-861.

49. Batais MA, Khan AR, Bin AA (2017) The Use of Statins and Risk of CommunityAcquired Pneumonia. Curr Infect Dis Rep 19: 26

50. Peel JL, Tolbert PE, Klein M, Metzger KB, Flanders WD, et al. (2005) Ambient air pollution and respiratory emergency department visits. Epidemiology 16: 164-174

51. Cheng MF, Tsai SS, Wu TN, Chen PS, Yang CY (2007) Air pollution and hospital admissions for pneumonia in a tropical city: Kaohsiung, Taiwan. $J$ Toxicol Environ Health A 70: 2021-2026.

52. Medina-Ramon M, Zanobetti A, Schwartz J (2006) The effect of ozone and PM10 on hospital admissions for pneumonia and chronic obstructive pulmonary disease: A national multicity study. Am J Epidemiol 163: 579-588.

53. Lin H, Ma W, Qiu H, Vaughn MG, Nelson EJ, et al. (2016) Is standard deviation of daily PM2.5 concentration associated with respiratory mortality? Environ Pollut 216: 208-214

54. Zhao Y, Wang S, Lang L, Huang C, Ma W, et al. (2017) Ambient fine and coarse particulate matter pollution and respiratory morbidity in Dongguan, China. Environ Pollut 222: 126-131.

55. Aston SJ (2017) Pneumonia in the developing world: Characteristic features and approach to management. Respirol 22: 1276-1287.

56. Nhung N, Amini H, Schindler C, Kutlar JM, Dien TM, et al. (2017) Shortterm association between ambient air pollution and pneumonia in children: A systematic review and meta-analysis of time-series and case-crossover studies. Environ Pollut 230: 1000-1008.

57. Neupane B, Jerrett M, Burnett RT, Marrie T, Arain A, et al. (2010) Long-term exposure to ambient air pollution and risk of hospitalization with communityacquired pneumonia in older adults. Am J Respir Crit Care Med 181: 47-53.

58. Souza LS, Nascimento LF (2016) Air pollutants and hospital admission due to pneumonia in children: a time series analysis. Rev Assoc Med Bras (1992) 62: 151-156.

59. Maclntyre EA, Gehring U, Molter A, Fuertes E, Klumper C, et al. (2014) Air pollution and respiratory infections during early childhood: An analysis of 10 European birth cohorts within the ESCAPE Project. Environ Health Perspect 122: $107-113$.

60. Fuertes E, Maclntyre E, Agius R, Beelen R, Brunekreef B, et al. (2014) Associations between particulate matter elements and early-life pneumonia in seven birth cohorts: Results from the ESCAPE and TRANSPHORM projects. Int J Hyg Environ Health 217: 819-829.

61. Trachootham D, Lu W, Ogasawara MA, Valle NR, Huang P (2007) Redox Regulation of Cell Survival. Antioxid Redox Sign 10: 1343-1374.

62. Li N, Hao M, Phalen RF, Hinds WC, Nel AE (2003) Particulate air pollutants and asthma. A paradigm for the role of oxidative stress in PMinduced adverse health effects. Clin Immunol 109: 250-265.

63. Li N, Kim S, Wang M, Froines J, Sioutas C, et al. (2002) Use of a stratified oxidative stress model to study the biological effects of ambient concentrated and diesel exhaust particulate matter. Inhal Toxicol 14: 459-486.

64. Yan Z, Wang J, Li J, Jiang N, Zhang R, et al. (2016) Oxidative stress and endocytosis are involved in upregulation of interleukin-8 expression in airway cells exposed to PM2.5. Environ Toxicol 31: 1869-1878.

65. Su R, Jin X, Zhang W, Li Z, Liu X, et al. (2017) Particulate matter exposure induces the autophagy of macrophages via oxidative stress-mediated PI3K AKT/mTOR pathway. Chemosphere 167: 444-453.

66. Wang J, Huang J, Wang L, Chen C, Yang D, et al. (2017) Urban particulate matter triggers lung inflammation via the ROS-MAPK-NF-kappaB signaling pathway. J Thorac Dis 9: 4398-4412.

67. Li N, Wang M, Oberley TD, Sempf JM, Nel AE (2002) Comparison of the pro-oxidative and proinflammatory effects of organic diesel exhaust particle chemicals in bronchial epithelial cells and macrophages. J Immunol 169: 4531-4541.

68. Gurgueira SA, Lawrence J, Coull B, Murthy GG, Gonzalez-Flecha B (2002) Rapid increases in the steady-state concentration of reactive oxygen species in the lungs and heart after particulate air pollution inhalation. Environ Health Perspect 110: 749-755.

69. Jin Y, Wu W, Zhang W, Zhao Y, Wu Y, et al. (2017) Involvement of EGF receptor 
signaling and NLRP12 inflammasome in fine particulate matter-induced lung inflammation in mice. Environ Toxicol 32: 1121-1134.

70. Kim HJ, Choi MG, Park MK, Seo YR (2017) Predictive and Prognostic Biomarkers of Respiratory Diseases due to Particulate Matter Exposure. $J$ Cancer Prev 22: 6-15.

71. Yan Z, Jin Y, An Z, Liu Y, Samet JM, et al. (2016) Inflammatory cell signaling following exposures to particulate matter and ozone. Biochim Biophys Acta 1860: 2826-2834.

72. Jeong SC, Cho Y, Song MK, Lee E, Ryu JC (2017) Epidermal growth factor receptor (EGFR)-MAPK-nuclear factor(NF)-kappaB-IL8: A possible mechanism of particulate matter(PM) 2.5-induced lung toxicity. Environ Toxicol 32: 16281636.

73. Zhang X, Zhong W, Meng Q, Lin Q, Fang C, et al. (2015) Ambient PM2.5 exposure exacerbates severity of allergic asthma in previously sensitized mice. J Asthma 52: 785-794.

74. Chu X, Liu XJ, Qiu JM, Zeng XL, Bao HR, et al. (2016) Effects of Astragalus and Codonopsis pilosula polysaccharides on alveolar macrophage phagocytosis and inflammation in chronic obstructive pulmonary disease mice exposed to PM2.5. Environ Toxicol Pharmacol 48: 76-84.

75. Peixoto MS, de Oliveira GM, Batistuzzo DMS (2017) Cell death pathways of particulate matter toxicity. Chemosphere 188: 32-48.

76. Deng X, Zhang F, Wang L, Rui W, Long F, et al. (2014) Airborne fine particulate matter induces multiple cell death pathways in human lung epithelial cells. Apoptosis 19: 1099-1112.

77. Soberanes S, Panduri V, Mutlu GM, Ghio A, Bundinger GR, et al. (2006) p53 mediates particulate matter-induced alveolar epithelial cell mitochondria-regulated apoptosis. Am J Respir Crit Care Med 174: 12291238.

78. Zhou W, Yuan X, Zhang L, Su B, Tian D, et al. (2017) Overexpression of HO-1 assisted PM2.5-induced apoptosis failure and autophagy-related cell necrosis. Ecotoxicol Environ Saf 145: 605-614.

79. Schiliro T, Alessandria L, Degan R, Traversi D, Gilli G (2010) Chemical characterisation and cytotoxic effects in A549 cells of urban-air PM10 collected in Torino, Italy. Environ Toxicol Pharmacol 29: 150-157.

80. Santibanez-Andrade M, Quezada-Maldonado EM, Osornio-Vargas A, Sanchez Perez Y, Garcia-Cuellar CM (2017) Air pollution and genomic instability: The role of particulate matter in lung carcinogenesis. Environ Pollut 229: 412-422.

81. Hornberg C, Maciuleviciute L, Seemayer NH, Kainka E (1998) Induction of sister chromatid exchanges (SCE) in human tracheal epithelial cells by the fractions PM-10 and PM-2.5 of airborne particulates. Toxicol Lett 96-97: 215220

82. Steiner S, Bisig C, Petri-Fink A, Rothen-Rutishauser B (2016) Diesel exhaust current knowledge of adverse effects and underlying cellular mechanisms. Arch Toxicol 90: 1541-1553.

83. Yu XJ, Yang MJ, Zhou B, Wang GZ, Huang YC, et al. (2015) Characterization of Somatic Mutations in Air Pollution-Related Lung Cancer. EBioMedicine 2 583-590.

84. Baccarelli A, Wright RO, Bollati V, Tarantini L, Litonjua AA, et al. (2009) Rapid DNA methylation changes after exposure to traffic particles. Am J Respir Crit Care Med 179: 572-578.

85. Chen R, Qiao L, Li H, Zhao Y, Zhang Y, et al. (2015) Fine Particulate Matter Constituents, Nitric Oxide Synthase DNA Methylation and Exhaled Nitric Oxide. Environ Sci Technol 49: 11859-11865

86. Liu C, Xu J, Chen Y, Guo X, Zheng Y, et al. (2015) Characterization of genomewide $\mathrm{H} 3 \mathrm{~K} 27$ ac profiles reveals a distinct PM2.5-associated histone modification signature. Environ Health 14: 65.

87. Ding R, Jin Y, Liu X, Zhu Z, Zhang Y, et al. (2016) H3K9 acetylation change patterns in rats after exposure to traffic-related air pollution. Environ Toxicol Pharmacol 42: 170-175.

88. Guan WJ, Zheng XY, Chung KF, Zhong NS (2016) Impact of air pollution on the burden of chronic respiratory diseases in China: Time for urgent action. Lancet 388: 1939-1951.

89. Tanpowpong K (2000) Personal respiratory protective devices: Efficacy of intranasal stent with filters. J Med Assoc Thai 83: 21-27. 